\title{
Impact of Phytoplankton Blooms on Concentrations of Antibiotics in Sediment and Snails in a Subtropical River, China
}

3

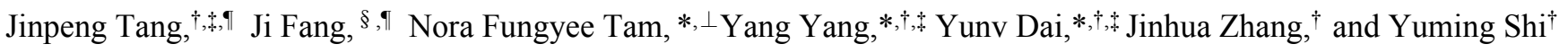

4

$\dagger$ Research Center of Hydrobiology, Department of Ecology, Jinan University, Guangzhou 510632, China

$\$$ Engineering Research Center of Tropical and Subtropical Aquatic Ecological Engineering, Ministry of Education, Guangzhou 510632, China

$\S$ Institute of public health, Guangzhou institutes of biomedicine and health, Chinese academy of sciences, Guangzhou 510530, China

$\perp$ School of Science and Technology, The Open University of Hong Kong, Ho Man Tin, Kowloon, Hong Kong Special Administrative Region, China

I These authors contributed to the work equally and should be regarded as co-first authors.

Total number of pages: 23

14 Page S2: Description of study area; Environmental sampling and analyses; Phytoplankton sampling and analyses.

Page S3: Sample extraction

Page S4-5: Instrumental conditions; Quality assurance and quality control and statistical analysis; Burial, and diffusion determinations.

17 Pages S6-18: Tables S1-S12.

Pages S19-21: Figs S1-13.

Pages S22-23: Reference 


\section{Description of study area}

The Pearl River, located in tropical and subtropical areas of Southeast Asia $\left(21.31^{\circ}-26.49^{\circ} \mathrm{N}\right.$ and $\left.102.14^{\circ}-115.53^{\circ} \mathrm{E}\right)$, receives water from numerous tributaries and has a total watershed area of $4.5 \times 10^{5} \mathrm{~km}^{2}$, a mean annual precipitation of $1,470 \mathrm{~mm}$ and a mean annual runoff discharge of 320 billion $\mathrm{m}^{3}$ year ${ }^{-1} .^{1}$ The Pearl River is the second largest river in China and flows through the central city of Guangzhou, one of the most densely populated industrial cities in China (Fig. 1). Upstream the Pearl River divides into three main tributaries, namely East River, West River and North River. The total length of the primary channel of the Pearl River (named as Major Pearl River) is $128 \mathrm{~km}$ and divides into two water ways: (i) Guangzhou Channel (the upper reach) with a length of $78 \mathrm{~km}$, an average width of $431 \mathrm{~m}$ and water depth of $4.8 \mathrm{~m}$; and (ii) Shiziyang Channel (the lower reach) with a length of $50 \mathrm{~km}$, width of 2,200 m and water depth of $6.6 \mathrm{~m}$. The Shiziyang Channel also receives inflows from the Guangzhou Channel and the East River, and runs across the well-developed agricultural and industrial regions, including Panyu and Dongguan. ${ }^{2}$ Over the past several decades, the Pearl River Delta has experienced rapid agricultural, industrial and urban developments. Due to the overuse of antibiotics and the discharge of domestic and industrial sewage, both the water quality and aquatic organisms in the Pearl River are polluted by antibiotics. ${ }^{3-5}$

Due to the discharge of aquaculture and domestic sewage in the rural areas of the lower Liuxi River, concentrations of antibiotics in water are relatively high at upstream of the Pearl River, particularly sulfonamides and macrolides as they have been widely used for treating diseases and promoting aquaculture production in China. The direct discharge of untreated domestic and municipal sewage into the heavily contaminated Shijing River also leads to a high concentration of roxithromycin (RTM) of up to $2260 \mathrm{ng} \mathrm{L}^{-1} \cdot 6$

\section{Environmental sampling and analyses}

Surface sediments $(0-2 \mathrm{~cm})$ were collected using a sediment gravity corer. Three cores were collected at each site at the same time, and about 3,000 g (wet mass) from the superficial $2 \mathrm{~cm}$ were mixed and formed a composite sample. Any pebbles and twigs were removed before mixed thoroughly. The on-ice samples of sediment were sent to the laboratory and then freeze-dried within $24 \mathrm{~h}$ to minimize the alteration in sample constituents and to avoid the need to preserve or stabilize samples. Ground samples were stored at $-20^{\circ} \mathrm{C}$ until extraction. Water $(10 \mathrm{~L})$ samples was collected at each location and placed into brown glass bottles. Then, samples were transported and stored at $4{ }^{\circ} \mathrm{C}$ and extracted within $24 \mathrm{~h}$. The associated bottles were combusted at $450{ }^{\circ} \mathrm{C}$ for $4 \mathrm{~h}$, and then pre-cleaned with high-purity n-hexane (Merck Darmstadt, Germany), dichloromethane (Tedia Co. Ltd, Fairfield, OH, USA), acetone (Tedia Co. Ltd, Fairfield, OH, USA), methanol (Tedia Co. Ltd, Fairfield, OH, USA) and Milli-Q water. Bottles were also washed with water samples for 3 times before sample collection. For the analysis of total nitrogen (TN) and total phosphorus (TP), the composite water sample was stored in a $250 \mathrm{~mL}$ polyethylene bottle and transported to the laboratory in a cooler box, $3.5 \mathrm{~mL} \mathrm{HNO}_{3}$ was then added to each water sample and preserved at $-4{ }^{\circ} \mathrm{C}$ prior to analyses. The concentrations of TN and TP in approximately $100 \mathrm{~mL}$ composite water sample was determined using the standard alkaline potassium persulfate oxidation method described by previous work. ${ }^{7}$

\section{Phytoplankton sampling and analyses}

To analyze the composition, abundance and biomass of phytoplankton community, 2 liters of surface water (0-30 $\mathrm{cm})$ was collected at each sampling site. ${ }^{8-10}$ 
Lugol's iodine was added to the filtrate containing phytoplankton sample for preservation, settled for $48 \mathrm{~h}$ and concentrated to $30 \mathrm{~mL}$. The phytoplankton species was identified according to previous study. ${ }^{11}$ The cell density of each species was counted by a Sedgwick-Rafter counting chamber (Pyser-SGI Limited, UK) using a light microscope (Olympus CX31; Olympus Corp.) at magnifications between $200 \times$ and $400 \times$, and the cell size was also measured by the same microscope. The total biovolume of each species was calculated based on the cell number and cell size. The amount of biomass was obtained by converting the cell volume (from the cell shape of each species ) into biomass assuming that $1 \mathrm{~mm}^{3}$ was equivalent to $1 \mathrm{mg}$ fresh weight biomass according to previous work. ${ }^{12}$ The remaining phytoplankton samples were freeze-dried, weighted and stored at $-18^{\circ} \mathrm{C}$ for further analysis of antibiotics.

\section{Sample extraction}

Water. Water sample was not filtered. Solid phase extraction (SPE) was performed for each water sample (5L) using two tandem Oasis HLB cartridges (500 mg/ $6 \mathrm{~mL}$, Waters, USA). In brief, the cartridges were activated and conditioned with $10 \mathrm{ml}$ high-purity hexane, dichloromethane, acetone, methanol and Mili-Q water sequentially, while water was extracted under vacuum at a flow rate of 5-8 $\mathrm{mL} \mathrm{min} \mathrm{m}^{-1}$. Approximately $1 \mathrm{~L}$ sample was passed through two tandem cartridges to avoid over filtration, and ten cartridges were used for the water samples from one site $((5 \mathrm{~L} / 1 \mathrm{~L}) \times 2$ cartridges $=10$ cartridges $)$. Then, the column was dried completely under a gentle stream of nitrogen gas $(99.999 \%$ pure). Chemicals were eluted with $10 \mathrm{~mL}$ methanol, followed by $10 \mathrm{~mL}$ acetone: methanol (1:1). The SPE extracts were combined into a composite sample and concentrated by rotary evaporation (type TVE-1000, EYELA, Tokyo, Japan) in a thermostatic bath. The milli-Q water used as the procedure blanks was also extracted according to the above-mentioned procedure.

Sediment, phytoplankton and snails. The targeted residues were extracted based on a slightly modified QuEChERS methodology as previously described. ${ }^{13-15}$ Briefly, a $50 \mathrm{~mL}$ polypropylene tube was used to weigh $0.1-0.5 \mathrm{~g}$ of the sample, $100 \mu \mathrm{L}$ a mixed spike solution was added, and the tube was placed in darkness overnight. The following day, $20 \mathrm{~mL}$ of $5 \%$ acetic-ACN and $0.1 \mathrm{M}$ EDTA-McIlvaine buffer $(1: 1$, v/v, pH=4) were added. To ensure that the solvent interacted well with the entire sample, the tube was swirled for $1 \mathrm{~min}$ and then centrifuged at $8000 \mathrm{rpm}$ for $10 \mathrm{~min}$. The supernatant was transferred into a $50 \mathrm{~mL}$ centrifuge tube and the operation was repeated to extract the settled solid. Solid $\mathrm{NaCl}(1 \mathrm{~g})$ and $\mathrm{Na}_{2} \mathrm{SO}_{4}(4 \mathrm{~g})$ were added to a total $40 \mathrm{~mL}$ collected supernatant. Then, the tube was immediately sealed and vigorously shaken by hand for $1 \mathrm{~min}$ and then centrifuged at $5000 \mathrm{rpm}$ for 5 min. The supernatant (organic phase) was pipetted into a 50 mL centrifuge tube and the volume of solution was made up with ACN to $20 \mathrm{~mL}$. An aliquot of $4 \mathrm{~mL}$ organic phase was transferred into a $10 \mathrm{~mL}$ polypropylene centrifuge tube, which contained $50 \mathrm{mg}$ of PSA sorbent, $150 \mathrm{mg} \mathrm{C}$, and $900 \mathrm{mg} \mathrm{Na} \mathrm{SO}_{4}$. The mixture was mixed in a vortex for 2 min until the adsorbent was thoroughly dispersed and centrifuged again at $4000 \mathrm{rpm}$ for $5 \mathrm{~min}$. The supernatant was collected in a glass tube and evaporated under nitrogen flow to approximately $0.2 \mathrm{~mL}$, and $0.8 \mathrm{~mL}$ of ACN- $0.1 \%$ formic acid aqueous solution $(20: 80, \mathrm{v} / \mathrm{v})$ was added. The re-dissolved solution was then filtered through a $0.22 \mu \mathrm{m}$ nylon membrane filter

(Anpel, Shanghai, China) and transferred to a $1 \mathrm{~mL}$ glass sample vial prior to analysis under the optimized conditions. 


\section{Instrumental conditions}

Antibiotics were analyzed using liquid chromatography coupled with electrospray ionization tandem mass spectrometry (LC-ESI-MS/MS) in multiple reaction monitoring (MRM) model with unit mass resolution was used to analyse target antibiotics. For high-performance liquid chromatography (HPLC), separation of the extracted target antibiotics was performed with the use of Ultimate 3000 HPLC separation module system (Dionex, USA) equipped with a C18 column (Waters, 3.5 $\mu \mathrm{m}, 4.6 \times 150 \mathrm{~mm}$ ). The mobile phase was used for gradient elution, which contained $0.1 \%$ formic acid supplemented within the ultrapure water (eluent A) and ACN containing $0.1 \%$ formic acid (eluent B), respectively. A positive electrospray ionization mode (ESI+) with optimized parameters was proposed to analyze the mass spectrometer: drying gas temperature at $325^{\circ} \mathrm{C}$, flow rate: $6 \mathrm{~L} \mathrm{~min}^{-1}$, capillary voltage: $3,500 \mathrm{~V}$, nozzle voltage: $0 \mathrm{~V}$, the nebulizing gas pressure: 45 psi, the sheath gas was set at $350^{\circ} \mathrm{C}$, and flow rate: $11 \mathrm{~L} \mathrm{~min}^{-1}$. Nitrogen was used as the drying and collision gas. The injection volume was $10 \mu \mathrm{L}$.

\section{QA/QC and statistical analysis}

During the process of instrumental analysis, internal standards including Sulfamethazine- ${ }^{13} \mathrm{C}_{6}$, Sulfamethoxazole-- $\mathrm{D}_{4}$, Thiabendazole- $\mathrm{D}_{4}$, Ciprofloxacin- $\mathrm{D}_{8}$, Erythromycin $-{ }^{13} \mathrm{C}-\mathrm{D}_{3}$ and Trimethoprim- $\mathrm{D}_{3}$ were added to the tested extracts before instrumental analysis for quality control of antibiotics. The regression coefficients $\left(\mathrm{r}^{2}\right)$ of calibration curves for all target chemicals were greater than 0.99 as shown in Table S2.

Blank runs of the chromatograph and direct injections of methanol were made to check the presence of target compounds in the chromatographic system. None of the target compound was present in the chromatogram. In the present study, procedural blank analyses were initially carried out with Milli-Q water, pre-extracted sediment and phytoplankton for water, sediment and phytoplankton samples separately. The recovery tests were conducted by spiking each target compound into procedure blank samples and on field samples. The spiked levels of antibiotics in both sediments and phytoplankton were 10,50 and 200 ng $\mathrm{g}^{-1} \mathrm{~d} . \mathrm{w}$., while those in water were 10, 50 and $100 \mathrm{ng} \mathrm{L}^{-1}$. Three replicates were conducted for QA/QC. The recoveries of investigated antibiotics ranged from $71 \%$ to $111 \%$. The estimated limit of detection (LOD), defined as the sample concentrations at signal-to-noise ratio ( $\mathrm{S} / \mathrm{N})$ of 3 , for individual antibiotic in water, sediment and biota samples are listed in Table S2.

During sample analysis, quality control samples consisted of duplicate samples, calibration check standards and solvent blanks. Duplicate samples were used to assure the precision and accuracy of each batch of samples, and the deviations of duplicate samples were less than $20 \%$. Calibration check standards were run after every ten samples to check the instrument. If the calibration check standards were out of $\pm 20 \%$ of its theoretical value based on the calibration curve, a new calibration curve was prepared. Solvent blanks were run prior to every ten samples to check the instrumental background.

Bioconcentration of contaminants by phytoplankton. Knowledge of bioconcentration of organic contaminants by phytoplankton is essential to understand the factors that control the bioaccumulation and biomagnification in the food web of the lake. ${ }^{16}$ The lower levels of the trophic web induce longer persistence and magnification potential for the organic contaminants, which also lead to biomagnification and greater concentrations and potential risks to health of predators. ${ }^{17}$ The bioconcentration factor (BCF) value for lipophilic chemicals decreased slightly at the same location with time, which showed greater variability for different chemicals, making it difficult to understand the transfer trends in water and phytoplankton. This is consistent with the results of a study in Lake Maggiore in Italy. ${ }^{18}$ Variations in BCF during blooms of cyanophyceae are partially due to changes in the overall abundance of phytoplankton as well as the species present in the assemblage. ${ }^{19}$ Initially blooms consisted primarily of Melosira spp., which was then followed by Cyclotella.spp in Pearl River. ${ }^{8}$ Thus, greater variability in concentrations measured in the 
water column was found, which was consistent with observed in our previous work. ${ }^{20}$

Transfer trends in water and phytoplankton. The water-phytoplankton flux is useful to give estimates of contaminants derived from the decrease in water column concentrations. When $F_{\mathrm{P}-\mathrm{W}}$ was calculated for chemicals, $F_{\mathrm{P}-\mathrm{W}}$ was negative during the season when phytoplankton blooms occurred, and the net flux was from water to phytoplankton. Therefore, the water-to-phytoplankton system was presumed to be in disequilibrium during blooms. This trend became especially strong during the period of maximum biomass. During the period of maximum biomass, the flux of SMZ, SMX and ETM into phytoplankton was greater. Moreover, the greater fluxes of biogenic matter during the summer depleted the concentrations in water column, which resulted in greater decreases in concentrations of chemicals during the periods of phytoplankton blooms. Results of previous studies indicated that annual blooms of phytoplankton sink to the sediment as they die. Therefore, it is suspected that, during the life cycle of phytoplankton, contaminants are accumulated, and when algae die and settle to the bottom, the organic chemicals are released from the water column, which increase the concentrations in surface sediments in the more eutrophic portions of rivers.

\section{Burial, and Diffusion Determinations}

Rate of $F_{\text {seddiff }}\left(n g \mathrm{~m}^{-2} \mathrm{~d}^{-1}\right)$ represents the flux of dissolved compounds due to diffusion between sediment and water, while $\mathrm{F}_{\text {burial }}\left(\mathrm{ng} \mathrm{m}^{-2} \mathrm{~d}^{-1}\right.$ ) is the flux of compounds from the surface to the permanent sediment layers. In the calculation of $\mathrm{F}_{\text {seddiff }}($ Equations $(\mathrm{S} 1))$ and $\mathrm{F}_{\text {burial }}\left(\mathrm{Equations}(\mathrm{S} 2)\right.$ and $(\mathrm{S} 3)$ assuming that $\mathrm{F}_{\mathrm{OM}}$ is equal to the vertical flux of organic carbon $\left(\mathrm{F}_{\mathrm{OC}}\right)$ ), the concentrations of antibiotics in sediments were not normalized to the concentration of total organic carbon as antibiotic concentrations were presented in terms of dry weight.

$\mathrm{F}_{\text {seddiff }}=-\mathrm{k}_{\text {seddiff }}\left(\mathrm{C}_{\mathrm{w}}-\frac{\mathrm{C}_{\mathrm{s}}}{\mathrm{K}_{\text {sed }}}\right)(\mathrm{S} 1)$

where $\mathrm{C}_{\mathrm{S}}$ is the concentration in sediment $\left(\mathrm{ng} \mathrm{kg}^{-1}\right), \mathrm{K}_{\text {sed }}$ is the sediment water partition coefficient $\left(\mathrm{m}^{3} \mathrm{~kg}^{-1}\right)$ calculated based on the previous study using $\mathrm{f}_{\mathrm{oc}}=0.041 .^{21}$ In addition, $\mathrm{C}_{\mathrm{s}} / \mathrm{K}_{\text {sed }}$ is taken as the dissolved concentration in the pore water of the sediment (ng m $\left.{ }^{-3}\right)$, while $\mathrm{k}_{\text {seddiff }}$ is the sediment-water diffusion coefficient $\left(\mathrm{m} \mathrm{d}^{-1}\right)$, which is estimated as 0.08 according to previous work. ${ }^{22-24}$

$\mathrm{F}_{\text {burial }}=\mathrm{F}_{\text {settling }} \mathrm{C}_{\mathrm{s}}$

$\mathrm{F}_{\text {settling }}=\mathrm{F}_{\mathrm{OM}} \times 2 \mathrm{~kg} \mathrm{~m}^{-2} \mathrm{~d}^{-1}$

In Equation (S3), $2 \mathrm{~kg} \mathrm{~m}^{-2} \mathrm{~d}^{-1}$ is the amount of particulate matter added to the surface mixed sediment layer (SMSL) per unit area per time that re-suspends, ${ }^{32}$ assuming the thickness of SMSL is constant, i.e., the amount of particulate matter buried in the permanent sediment layer equals the amount of particulate matter added to the SMSL through settling. ${ }^{25}$ 
Table S1 Names and abbreviations of the target antibiotics and internal standards (IS) used in this study.

\begin{tabular}{|c|c|c|c|c|c|}
\hline \multicolumn{2}{|l|}{ Class } & \multicolumn{2}{|c|}{ Compound } & \multirow[t]{2}{*}{ Log Kow } & \multirow{2}{*}{ IS used } \\
\hline Name & Abbreviation & Name & Abbreviation & & \\
\hline \multirow[t]{6}{*}{ Internal standards } & IS & Sulfamethazine $-{ }^{13} \mathrm{C}_{6}$ & $\mathrm{SMZ}-{ }^{13} \mathrm{C}_{6}$ & & \\
\hline & & Sulfamethoxazole- $\mathrm{D}_{4}$ & SMX-D 4 & & \\
\hline & & Thiabendazole- $\mathrm{D}_{4}$ & TBD-D 4 & & \\
\hline & & Ciprofloxacin- $\mathrm{D}_{8}$ & $\mathrm{CFX}_{-} \mathrm{D}_{8}$ & & \\
\hline & & Erythromycin- ${ }^{13} \mathrm{C}-\mathrm{D}_{3}$ & ETM- $-{ }^{13} \mathrm{C}-\mathrm{D}_{3}$ & & \\
\hline & & Trimethoprim- $\mathrm{D}_{3}$ & $\mathrm{TMP}^{-\mathrm{D}_{3}}$ & & \\
\hline \multirow[t]{6}{*}{ Sulfonamide } & SAs & Sulfamethoxazole & SMX & 0.89 & $\mathrm{SMX}-\mathrm{D}_{4}$ \\
\hline & & Sulfamethazine & SMZ & 0.14 & $\mathrm{SMZ}-{ }^{13} \mathrm{C}_{6}$ \\
\hline & & Sulfapyridine & SPD & 0.03 & $\mathrm{SMZ}-{ }^{13} \mathrm{C}_{6}$ \\
\hline & & Sulfacetamide & SCT & -0.96 & SMX-D 4 \\
\hline & & Sulfadiazine & SDZ & 0.39 & $\mathrm{SMX}-\mathrm{D}_{4}$ \\
\hline & & Trimethoprim & TMP & 0.79 & $\mathrm{TMP}^{-\mathrm{D}_{3}}$ \\
\hline \multirow[t]{4}{*}{ Fluoroquinolone } & FQs & Norfloxacin & NFX & 0.46 & CFX-D 8 \\
\hline & & Ciprofloxacin & CFX & 0.28 & $\mathrm{CFX}-\mathrm{D}_{8}$ \\
\hline & & Ofloxacin & OFX & -0.39 & $\mathrm{CFX}-\mathrm{D}_{8}$ \\
\hline & & Lomefloxacin & LFX & -0.30 & CFX-D 8 \\
\hline \multirow[t]{2}{*}{ Macrolide } & MLs & Erythromycin & ETM & 3.06 & ETM- ${ }^{13} \mathrm{C}-\mathrm{D}_{3}$ \\
\hline & & Roxithromycin & RTM & 1.70 & ETM- ${ }^{13} \mathrm{C}-\mathrm{D}_{3}$ \\
\hline \multirow[t]{2}{*}{ Tetracycline } & TCs & Oxytetracycline & OTC & -0.90 & $\mathrm{TBD}^{-\mathrm{D}_{4}}$ \\
\hline & & Tetracycline & $\mathrm{TC}$ & -1.37 & TBD-D 4 \\
\hline
\end{tabular}


Table S2 Regression coefficients $\left(\mathrm{r}^{2}\right)$, recoveries (\%) and limits of detection (LODs, $\mathrm{S} / \mathrm{N}=3$ ) of 14 detected antibiotics in Pearl River.

\begin{tabular}{|c|c|c|c|c|c|c|c|c|c|}
\hline \multirow{4}{*}{ Category } & \multirow{4}{*}{ Analytes } & \multirow{4}{*}{$\begin{array}{l}\text { Internal Standard } \\
\text { (IS used) }\end{array}$} & \multirow{4}{*}{$\mathrm{r}^{2}$} & \multicolumn{3}{|c|}{ Recovery (\%) } & \multicolumn{3}{|c|}{ LODs } \\
\hline & & & & & & & & & \\
\hline & & & & & & & & & \\
\hline & & & & Water & Sectintit & Divia & $\left(\operatorname{ng~L}^{-1}\right)$ & $\left(\mu \mathrm{g} \mathrm{kg}^{-1}\right)$ & $\left(\mu \mathrm{g} \mathrm{kg}^{-1}\right)$ \\
\hline Sulfonamides & SDZ & SMX-D 4 & 0.9981 & $104.8 \pm 20.0$ & $94.4 \pm 18.5$ & $99.8 \pm 16.3$ & 0.06 & 0.02 & 0.02 \\
\hline \multirow[t]{5}{*}{ (SAs) } & SPD & $\mathrm{SMZ}-{ }^{13} \mathrm{C}_{6}$ & 0.9986 & $87.7 \pm 19.4$ & $105.5 \pm 20.9$ & $86.9 \pm 1.5$ & 0.04 & 0.09 & 0.12 \\
\hline & SCT & SMX-D 4 & 0.9989 & $88.5 \pm 10.6$ & $81.1 \pm-0.9$ & $87.0 \pm 4.4$ & 0.07 & 0.02 & 0.05 \\
\hline & SMZ & SMZ- ${ }^{13} \mathrm{C}_{6}$ & 0.9987 & $77.9 \pm 14.8$ & $90.2 \pm 1.4$ & $98.8 \pm 7.0$ & 0.03 & 0.02 & 0.07 \\
\hline & SMX & SMX-D 4 & 0.9977 & $84.6 \pm 8.1$ & $87.2 \pm 3.3$ & $101.9 \pm 13.9$ & 0.02 & 0.11 & 0.07 \\
\hline & TMP & TMP-D 3 & 0.9987 & $97.9 \pm 9.2$ & $90.9 \pm 2.3$ & $110.8 \pm 13.8$ & 0.02 & 0.07 & 0.09 \\
\hline Fluoroquinolone & NFX & $\mathrm{CFX}-\mathrm{D}_{8}$ & 0.9978 & $71.6 \pm 13.2$ & $92.3 \pm 14.0$ & $86.0 \pm 4.2$ & 0.07 & 0.06 & 0.05 \\
\hline \multirow[t]{3}{*}{ (FQs) } & CFX & CFX-D 8 & 0.9995 & $107.9 \pm 19.1$ & $93.1 \pm 19.0$ & $91.1 \pm-6.6$ & 0.07 & 0.01 & 0.08 \\
\hline & LFX & $\mathrm{CFX}-\mathrm{D}_{8}$ & 0.9984 & $85.3 \pm 3.0$ & $87.6 \pm 7.3$ & $87.4 \pm 2.0$ & 0.04 & 0.02 & 0.10 \\
\hline & OFX & $\mathrm{CFX}-\mathrm{D}_{8}$ & 0.9993 & $100.5 \pm 11.0$ & $86.5 \pm 10.0$ & $81.4 \pm 1.3$ & 0.09 & 0.13 & 0.10 \\
\hline Tetracyclines & OTC & TBD-D 4 & 0.9997 & $76.9 \pm 10.2$ & $83.8 \pm 9.2$ & $100.9 \pm 6.3$ & 0.11 & 0.11 & 0.12 \\
\hline (TCs) & $\mathrm{TC}$ & TBD-D 4 & 0.9987 & $81.7 \pm 3.7$ & $100.4 \pm 15.1$ & $111.0 \pm 15.1$ & 0.10 & 0.07 & 0.08 \\
\hline Macrolides & ETM & ETM- ${ }^{13} \mathrm{C}-\mathrm{D}_{3}$ & 0.9988 & $106.8 \pm 16.1$ & $98.4 \pm 22.0$ & $109.3 \pm 13.3$ & 0.02 & 0.08 & 0.07 \\
\hline (MLs) & RTM & ETM- ${ }^{13} \mathrm{C}-\mathrm{D}_{3}$ & 0.9998 & $96.0 \pm 7.3$ & $100.2 \pm 12.8$ & $98.8 \pm 14.6$ & 0.08 & 0.03 & 0.11 \\
\hline
\end{tabular}


Table S3 Distribution of sulfonamides (SAs) in surface sediments (ng $\cdot \mathrm{g}^{-1}$, d.w.). Concentrations are measured during the late blooming seasons in 2015,2016 and

$1392017(n=3)$. Samples are named as Letter, Number1-Number2 (letter represents type of matrix, while the first number represents the location where the sample is

140 taken and the second number represents the date of collection).

\begin{tabular}{|c|c|c|c|c|c|c|c|}
\hline Location and time & SDZ & SPD & SCT & SMZ & SMX & TMP & SAs \\
\hline Z1-2015 & 12.6 & 76.9 & 112.0 & 793.3 & 165.6 & 506.3 & 1666.7 \\
\hline Z1-2016 & 28.8 & 40.6 & 22.1 & 812.6 & 66.7 & 132.3 & 1103.1 \\
\hline Z1-2017 & 61.3 & 86.5 & 65.5 & 160.6 & 161.9 & 33.5 & 569.3 \\
\hline Z2-2015 & 62.2 & 160.4 & 82.5 & 295.1 & 76.8 & 121.0 & 798.0 \\
\hline Z2-2016 & 70.5 & 234.7 & 71.2 & 285.4 & 194.5 & 69.4 & 925.7 \\
\hline Z2-2017 & 86.3 & 68.8 & 120.6 & 239.4 & 102.4 & 244.8 & 862.3 \\
\hline Z3-2015 & 35.4 & 112.4 & 66.9 & 302.3 & 153.6 & 117.3 & 787.9 \\
\hline Z3-2016 & 71.8 & 129.3 & 103.6 & 263.2 & 120.2 & 107.8 & 795.9 \\
\hline Z3-2017 & 40.9 & 83.2 & 58.4 & 198.3 & 50.6 & 240.4 & 671.8 \\
\hline Z4-2015 & 38.1 & 95.5 & 41.9 & 216.4 & 191.0 & 70.9 & 653.6 \\
\hline Z4-2016 & 16.8 & 164.2 & 48.5 & 197.0 & 85.6 & 203.6 & 715.6 \\
\hline Z4-2017 & 47.6 & 70.6 & 44.0 & 223.7 & 56.8 & 110.4 & 553.0 \\
\hline Z5-2015 & 34.9 & 36.0 & 36.2 & 48.3 & 32.9 & 39.3 & 227.5 \\
\hline Z5-2016 & 13.1 & 16.0 & 16.1 & 81.5 & 52.5 & 68.8 & 248.0 \\
\hline Z5-2017 & 17.7 & 30.9 & 24.4 & 71.4 & 80.0 & 33.1 & 257.4 \\
\hline Z6-2015 & 15.5 & 25.8 & 14.8 & 38.2 & 26.4 & 24.7 & 145.3 \\
\hline Z6-2016 & 12.5 & 23.8 & 17.7 & 77.0 & 18.3 & 21.3 & 170.7 \\
\hline Z6-2017 & 24.3 & 35.7 & 27.4 & 41.0 & 69.7 & 43.6 & 241.7 \\
\hline Z7-2015 & 5.8 & 10.8 & 11.7 & 78.4 & 6.3 & 46.0 & 159.0 \\
\hline Z7-2016 & 24.5 & 28.9 & 36.6 & 64.2 & 56.6 & 68.8 & 279.6 \\
\hline Z7-2017 & 33.7 & 41.9 & 35.9 & 49.6 & 36.5 & 41.4 & 239.0 \\
\hline
\end{tabular}


Table S3 (cont.)

\begin{tabular}{|c|c|c|c|c|c|c|c|}
\hline Z8-2015 & 16.2 & 18.4 & 18.6 & 46.4 & 26.2 & 43.2 & 169.0 \\
\hline Z8-2016 & 12.1 & 17.3 & 13.3 & 84.3 & 37.2 & 59.7 & 223.7 \\
\hline Z8-2017 & 15.7 & 33.9 & 16.5 & 76.1 & 18.2 & 64.7 & 225.1 \\
\hline Z9-2015 & 21.1 & 22.5 & 15.4 & 43.0 & 32.6 & 38.2 & 172.8 \\
\hline Z9-2016 & 19.7 & 21.6 & 26.9 & 39.3 & 24.4 & 24.1 & 156.0 \\
\hline Z9-2017 & 15.2 & 33.2 & 13.4 & 49.2 & 39.0 & 4.3 & 154.3 \\
\hline Z10-2015 & 16.2 & 23.5 & 27.4 & 77.8 & 27.1 & 31.8 & 203.8 \\
\hline Z10-2016 & 15.6 & 24.3 & 18.6 & 53.6 & 31.7 & 32.1 & 175.9 \\
\hline Z10-2017 & 22.9 & 39.2 & 13.0 & 31.1 & 55.4 & 20.4 & 182.0 \\
\hline Z11-2015 & 14.2 & 25.5 & 20.0 & 52.1 & 23.9 & 10.4 & 146.1 \\
\hline Z11-2016 & 17.7 & 25.9 & 20.9 & 47.6 & 18.1 & 46.8 & 177.1 \\
\hline Z11-2017 & 15.0 & 31.7 & 14.1 & 68.2 & 60.0 & 13.0 & 202.0 \\
\hline
\end{tabular}

Table S4 Distribution of fluoroquinolones (FQs), tetracyclines (TCs) and macrolides (MLs) in surface sediments (ng $\left.\cdot \mathrm{g}^{-1}, \mathrm{~d} . \mathrm{w}.\right)$. Concentrations are measured during the late bloom seasons in 2015, 2016 and 2017(n=3). Samples are named as Letter, Number1-Number2 (letter represents type of matrix, while the first number represents the site where the sample is taken and the second number represents the date of collection).

\begin{tabular}{|c|c|c|c|c|c|c|c|c|c|c|c|}
\hline Location and time & NFX & CFX & LFX & OFX & FQs & OTC & $\mathrm{TC}$ & TCs & ETM & RTM & MLs \\
\hline Z1-2015 & 146.9 & 242.9 & 74.6 & 108.1 & 572.5 & 24.5 & 6.8 & 31.4 & 92.5 & 190.6 & 283.1 \\
\hline Z1-2016 & 171.1 & 380.8 & 50.1 & 72.6 & 674.7 & 45.7 & 13.3 & 59.0 & 350.4 & 568.6 & 919.0 \\
\hline Z1-2017 & 253.5 & 69.5 & 56.5 & 48.3 & 427.7 & 17.7 & 40.7 & 58.4 & 167.9 & 438.9 & 606.8 \\
\hline Z2-2016 & 156.2 & 210.3 & 79.3 & 95.5 & 541.2 & 75.3 & 65.8 & 141.2 & 128.6 & 219.0 & 347.5 \\
\hline Z2-2017 & 178.8 & 162.4 & 62.8 & 76.4 & 480.5 & 119.0 & 98.3 & 217.3 & 156.0 & 156.3 & 312.3 \\
\hline
\end{tabular}


Table S4 (cont.)

\begin{tabular}{|c|c|c|c|c|c|c|c|c|c|c|c|}
\hline Z3-2017 & 143.4 & 41.6 & 26.6 & 41.1 & 252.7 & 27.0 & 12.8 & 39.9 & 351.6 & 263.9 & 615.5 \\
\hline Z4-2015 & 54.4 & 53.8 & 29.4 & 38.8 & 176.4 & 26.1 & 14.4 & 40.5 & 38.5 & 139.0 & 177.4 \\
\hline Z4-2016 & 61.8 & 57.0 & 38.8 & 27.4 & 185.0 & 28.9 & 14.6 & 43.6 & 81.4 & 119.9 & 201.3 \\
\hline Z4-2017 & 30.3 & 57.1 & 39.2 & 18.3 & 144.8 & 19.4 & 13.7 & 33.2 & 353.0 & 265.2 & 618.2 \\
\hline Z5-2015 & 39.2 & 41.5 & 24.3 & 47.0 & 152.0 & 93.4 & 62.6 & 156.0 & 111.7 & 225.9 & 337.5 \\
\hline Z5-2016 & 16.4 & 21.2 & 7.4 & 62.7 & 107.7 & 131.4 & 84.5 & 215.9 & 26.2 & 24.5 & 50.8 \\
\hline Z5-2017 & 14.4 & 58.9 & 27.8 & 73.9 & 175.0 & 88.6 & 14.7 & 103.3 & 49.6 & 50.2 & 99.8 \\
\hline Z6-2015 & 15.3 & 17.8 & 29.4 & 89.7 & 152.2 & 80.6 & 19.9 & 100.6 & 13.2 & 38.3 & 51.5 \\
\hline Z6-2016 & 29.5 & 20.2 & 16.5 & 91.9 & 158.0 & 150.4 & 19.4 & 169.8 & 33.9 & 46.3 & 80.2 \\
\hline Z6-2017 & 13.0 & 26.0 & 27.9 & 107.8 & 174.7 & 227.1 & 39.6 & 266.7 & 57.1 & 60.9 & 117.9 \\
\hline Z7-2015 & 30.8 & 18.8 & 13.1 & 76.8 & 139.5 & 260.9 & 100.5 & 361.5 & 7.3 & 17.9 & 25.2 \\
\hline Z7-2016 & 27.3 & 24.3 & 91.4 & 82.9 & 225.8 & 52.4 & 23.8 & 76.2 & 101.8 & 149.2 & 251.0 \\
\hline Z7-2017 & 37.8 & 41.6 & 91.1 & 101.9 & 272.4 & 51.8 & 35.4 & 87.2 & 78.3 & 184.8 & 263.2 \\
\hline Z8-2015 & 24.3 & 24.1 & 14.4 & 117.6 & 180.4 & 173.8 & 66.9 & 240.7 & 17.2 & 42.0 & 59.2 \\
\hline Z8-2016 & 20.9 & 23.6 & 8.7 & 109.8 & 162.9 & 250.3 & 14.5 & 264.7 & 66.1 & 84.8 & 151.0 \\
\hline Z8-2017 & 33.6 & 20.4 & 59.5 & 79.3 & 192.7 & 93.1 & 33.0 & 126.2 & 35.7 & 51.0 & 86.7 \\
\hline Z9-2015 & 3.1 & 4.4 & 23.1 & 9.0 & 39.6 & 10.7 & 10.9 & 21.7 & 83.9 & 115.2 & 199.1 \\
\hline Z9-2016 & 16.5 & 7.4 & 23.5 & 9.2 & 56.6 & 19.1 & 4.3 & 23.4 & 95.0 & 131.2 & 226.3 \\
\hline Z9-2017 & 4.5 & 14.3 & 21.6 & 12.7 & 53.0 & 20.4 & 9.4 & 29.8 & 53.2 & 135.6 & 188.8 \\
\hline Z10-2015 & 7.9 & 14.0 & 36.0 & 11.0 & 68.8 & 11.6 & 3.3 & 14.8 & 85.5 & 115.3 & 200.8 \\
\hline Z10-2016 & 6.7 & 7.6 & 27.9 & 9.6 & 51.8 & 23.0 & 11.7 & 34.7 & 53.4 & 136.3 & 189.7 \\
\hline Z10-2017 & 3.6 & 2.3 & 17.5 & 30.4 & 53.7 & 17.0 & 10.2 & 27.2 & 49.9 & 58.6 & 108.5 \\
\hline Z11-2015 & 3.8 & 10.3 & 23.0 & 36.8 & 73.8 & 13.8 & 14.9 & 28.7 & 86.4 & 131.8 & 218.2 \\
\hline Z11-2016 & 26.7 & 7.3 & 19.8 & 37.1 & 91.0 & 18.9 & 3.4 & 22.3 & 206.9 & 153.3 & 360.1 \\
\hline Z11-2017 & 8.8 & 14.2 & 22.9 & 34.9 & 80.8 & 18.3 & 5.3 & 23.6 & 33.9 & 154.5 & 188.4 \\
\hline
\end{tabular}


Table S5 Temporal variations of antibiotics in surface sediments $\left(\mathrm{ng} \cdot \mathrm{g}^{-1}, \mathrm{~d} . \mathrm{w}.\right)(\mathrm{n}=3)$ from March to September in 2018.

\begin{tabular}{|c|c|c|c|c|c|c|c|c|c|c|c|c|c|c|c|}
\hline Location & Time & SDZ & SPD & SCT & SMZ & SMX & TMP & NFX & CFX & LFX & OFX & OTC & $\mathrm{TC}$ & ETM & RTM \\
\hline $\mathrm{Z} 1$ & Mar. & 18.9 & 76.9 & 82.0 & 293.3 & 165.6 & 156.3 & 146.9 & 242.9 & 74.6 & 108.1 & 64.5 & 36.8 & 92.5 & 190.6 \\
\hline $\mathrm{Z} 1$ & Jul. & 24.1 & 40.6 & 22.1 & 312.6 & 66.7 & 132.3 & 171.1 & 280.8 & 50.1 & 72.6 & 45.7 & 23.3 & 150.4 & 368.6 \\
\hline $\mathrm{Z} 1$ & Sep. & 56.4 & 95.5 & 61.9 & 246.4 & 191.0 & 170.9 & 154.4 & 183.8 & 69.4 & 198.8 & 26.1 & 19.4 & 208.5 & 339.0 \\
\hline $\mathrm{Z} 2$ & Mar. & 17.8 & 25.9 & 20.9 & 47.6 & 18.1 & 46.8 & 26.7 & 7.3 & 19.8 & 37.1 & 108.9 & 43.4 & 156.9 & 153.3 \\
\hline $\mathrm{Z} 2$ & Jul. & 20.1 & 164.2 & 48.5 & 197.0 & 85.6 & 203.6 & 61.8 & 57.0 & 38.8 & 87.4 & 48.9 & 29.6 & 81.4 & 119.9 \\
\hline $\mathrm{Z} 2$ & Sep. & 38.7 & 68.9 & 46.6 & 194.2 & 156.6 & 108.8 & 127.3 & 124.3 & 91.4 & 142.9 & 52.4 & 18.8 & 201.8 & 249.2 \\
\hline $\mathrm{Z} 3$ & Mar. & 31.4 & 41.9 & 35.9 & 49.6 & 36.5 & 41.4 & 37.8 & 41.6 & 71.1 & 101.9 & 71.8 & 35.4 & 78.3 & 184.8 \\
\hline $\mathrm{Z3}$ & Jul. & 45.3 & 83.2 & 58.4 & 198.3 & 50.6 & 160.4 & 143.4 & 41.6 & 26.6 & 41.1 & 57.0 & 27.8 & 151.6 & 263.9 \\
\hline $\mathrm{Z} 3$ & Sep. & 57.0 & 86.5 & 65.5 & 160.6 & 161.9 & 93.5 & 253.5 & 69.5 & 56.5 & 128.3 & 35.7 & 20.7 & 167.9 & 438.9 \\
\hline Z9 & Mar. & 7.3 & 17.3 & 13.3 & 84.3 & 37.2 & 59.7 & 20.9 & 23.6 & 8.7 & 109.8 & 160.3 & 64.5 & 66.1 & 84.8 \\
\hline Z9 & Jul. & 17.5 & 16.0 & 16.1 & 81.5 & 52.5 & 68.8 & 16.4 & 21.2 & 7.4 & 62.7 & 121.4 & 59.5 & 26.2 & 24.5 \\
\hline Z9 & Sep. & 44.6 & 70.6 & 44.0 & 223.7 & 56.8 & 110.4 & 30.3 & 57.1 & 39.2 & 18.3 & 99.4 & 53.7 & 153.0 & 265.2 \\
\hline $\mathrm{Z} 10$ & Mar. & 14.2 & 33.9 & 16.5 & 76.1 & 18.2 & 64.7 & 33.6 & 20.4 & 59.5 & 79.3 & 93.1 & 53.0 & 35.7 & 51.0 \\
\hline $\mathrm{Z} 10$ & Jul. & 15.6 & 18.4 & 18.6 & 46.4 & 26.2 & 43.2 & 24.3 & 24.1 & 14.4 & 117.6 & 103.8 & 56.9 & 17.2 & 42.0 \\
\hline $\mathrm{Z} 10$ & Sep. & 16.2 & 31.7 & 14.1 & 68.2 & 60.0 & 13.0 & 8.8 & 14.2 & 22.9 & 34.9 & 78.3 & 35.3 & 33.9 & 154.5 \\
\hline Z11 & Mar. & 20.7 & 22.5 & 15.4 & 43.0 & 32.6 & 38.2 & 3.1 & 4.4 & 23.1 & 9.0 & 100.7 & 40.9 & 83.9 & 115.2 \\
\hline Z11 & Jul. & 18.6 & 25.5 & 20.0 & 52.1 & 23.9 & 10.4 & 3.8 & 10.3 & 23.0 & 36.8 & 113.8 & 34.9 & 86.4 & 131.8 \\
\hline Z11 & Sep. & 37.2 & 36.0 & 36.2 & 48.3 & 32.9 & 39.3 & 39.2 & 41.5 & 24.3 & 47.0 & 93.4 & 52.6 & 111.7 & 225.9 \\
\hline
\end{tabular}


Table S6 Temporal variations of antibiotics in water $\left(n g \cdot L^{-1}\right)(n=3)$ from March to September in 2018.

\begin{tabular}{|c|c|c|c|c|c|c|c|c|c|c|c|c|c|c|c|}
\hline Location & Time & SDZ & SPD & SCT & SMZ & SMX & TMP & NFX & CFX & LFX & OFX & OTC & $\mathrm{TC}$ & ETM & RTM \\
\hline $\mathrm{Z} 1$ & Mar. & 7.3 & 17.3 & 13.3 & 84.3 & 37.2 & 59.7 & 20.9 & 23.6 & 8.7 & 109.8 & 385.3 & 110.7 & 66.1 & 84.8 \\
\hline $\mathrm{Z} 1$ & Jul & 44.6 & 70.6 & 44.0 & 223.7 & 56.8 & 110.4 & 30.3 & 57.1 & 39.2 & 18.3 & 318.6 & 69.2 & 153.0 & 265.2 \\
\hline $\mathrm{Z} 1$ & Sep. & 18.9 & 76.9 & 82.0 & 293.3 & 165.6 & 156.3 & 146.9 & 242.9 & 74.6 & 108.1 & 136.0 & 50.7 & 92.5 & 190.6 \\
\hline $\mathrm{Z} 2$ & Mar. & 14.2 & 33.9 & 16.5 & 76.1 & 18.2 & 64.7 & 33.6 & 20.4 & 59.5 & 79.3 & 320.0 & 89.0 & 35.7 & 51.0 \\
\hline $\mathrm{Z} 2$ & Jul & 37.2 & 36.0 & 36.2 & 48.3 & 32.9 & 39.3 & 39.2 & 41.5 & 24.3 & 47.0 & 229.1 & 57.0 & 111.7 & 225.9 \\
\hline $\mathrm{Z} 2$ & Sep. & 24.1 & 40.6 & 22.1 & 312.6 & 66.7 & 132.3 & 171.1 & 280.8 & 50.1 & 72.6 & 150.0 & 37.9 & 150.4 & 368.6 \\
\hline $\mathrm{Z3}$ & Mar. & 20.7 & 22.5 & 15.4 & 43.0 & 32.6 & 38.2 & 3.1 & 4.4 & 23.1 & 9.0 & 266.3 & 72.8 & 83.9 & 115.2 \\
\hline $\mathrm{Z3}$ & Jul & 17.5 & 16.0 & 16.1 & 81.5 & 52.5 & 68.8 & 16.4 & 21.2 & 7.4 & 62.7 & 363.9 & 65.7 & 26.2 & 24.5 \\
\hline $\mathrm{Z3}$ & Sep. & 57.0 & 86.5 & 65.5 & 160.6 & 161.9 & 93.5 & 253.5 & 69.5 & 56.5 & 128.3 & 110.0 & 41.6 & 167.9 & 438.9 \\
\hline Z9 & Mar. & 18.6 & 25.5 & 20.0 & 52.1 & 23.9 & 10.4 & 3.8 & 10.3 & 23.0 & 36.8 & 160.0 & 45.4 & 86.4 & 131.8 \\
\hline Z9 & Jul & 38.7 & 68.9 & 46.6 & 194.2 & 156.6 & 108.8 & 127.3 & 124.3 & 91.4 & 142.9 & 96.0 & 35.5 & 201.8 & 249.2 \\
\hline Z9 & Sep. & 45.3 & 83.2 & 58.4 & 198.3 & 50.6 & 160.4 & 143.4 & 41.6 & 26.6 & 41.1 & 219.1 & 79.5 & 151.6 & 263.9 \\
\hline $\mathrm{Z} 10$ & Mar. & 17.8 & 25.9 & 20.9 & 47.6 & 18.1 & 46.8 & 26.7 & 7.3 & 19.8 & 37.1 & 127.1 & 44.2 & 156.9 & 153.3 \\
\hline Z10 & Jul & 31.4 & 41.9 & 35.9 & 49.6 & 36.5 & 41.4 & 37.8 & 41.6 & 71.1 & 101.9 & 294.7 & 70.5 & 78.3 & 184.8 \\
\hline Z10 & Sep. & 56.4 & 95.5 & 61.9 & 246.4 & 191.0 & 170.9 & 154.4 & 183.8 & 69.4 & 198.8 & 246.5 & 65.0 & 208.5 & 339.0 \\
\hline Z11 & Mar. & 16.2 & 31.7 & 14.1 & 68.2 & 60.0 & 13.0 & 8.8 & 14.2 & 22.9 & 34.9 & 130.0 & 45.7 & 33.9 & 154.5 \\
\hline Z11 & Jul & 15.6 & 18.4 & 18.6 & 46.4 & 26.2 & 43.2 & 24.3 & 24.1 & 14.4 & 117.6 & 307.6 & 57.3 & 17.2 & 42.0 \\
\hline Z11 & Sep. & 20.1 & 164.2 & 48.5 & 197.0 & 85.6 & 203.6 & 61.8 & 57.0 & 38.8 & 87.4 & 247.0 & 73.5 & 81.4 & 119.9 \\
\hline
\end{tabular}


Table S7 Temporal variations of antibiotics in phytoplankton and Bellamya purificata $\left(\mathrm{ng} \cdot \mathrm{g}^{-1}\right.$, d.w.) (n=3) from March to September in 2018.

\begin{tabular}{|c|c|c|c|c|c|c|c|c|c|c|c|c|c|c|c|}
\hline Location & Time & SDZ & SPD & $\mathrm{SCT}$ & SMZ & SMX & TMP & NFX & CFX & LFX & OFX & OTC & $\mathrm{TC}$ & ETM & RTM \\
\hline \multicolumn{16}{|c|}{ phytoplankton } \\
\hline $\mathrm{Z1}$ & Mar. & 13.9 & 7.7 & 9.4 & 8.6 & 26.9 & 33.6 & 79.0 & 43.7 & 18.0 & 90.6 & 4.6 & 4.4 & 122.5 & 88.7 \\
\hline $\mathrm{Z1}$ & Jul. & 12.6 & 7.9 & 31.6 & 31.9 & 23.7 & 20.2 & 43.8 & 14.8 & 23.2 & 45.5 & 4.2 & 2.0 & 113.2 & 20.8 \\
\hline $\mathrm{Z1}$ & Sep. & 10.5 & 6.2 & 25.6 & 28.2 & 21.1 & 20.5 & 31.7 & 21.6 & 6.9 & 35.0 & 3.8 & 1.6 & 97.5 & 30.4 \\
\hline $\mathrm{Z} 2$ & Mar. & 14.7 & 8.3 & 8.3 & 12.4 & 28.1 & 38.6 & 81.5 & 49.4 & 15.1 & 82.9 & 4.7 & 5.0 & 129.8 & 105.9 \\
\hline $\mathrm{Z} 2$ & Jul. & 13.3 & 7.2 & 14.3 & 6.4 & 25.6 & 37.0 & 81.9 & 55.5 & 10.4 & 96.5 & 4.7 & 4.6 & 110.8 & 106.8 \\
\hline $\mathrm{Z} 2$ & Sep. & 11.0 & 6.5 & 9.0 & 9.1 & 21.1 & 36.4 & 96.1 & 47.2 & 12.3 & 93.3 & 4.8 & 4.6 & 100.1 & 95.3 \\
\hline $\mathrm{Z3}$ & Mar. & 14.1 & 8.0 & 41.3 & 22.6 & 27.1 & 21.2 & 22.7 & 22.9 & 24.0 & 18.1 & 3.0 & 1.0 & 119.8 & 21.8 \\
\hline $\mathrm{Z3}$ & Jul & 13.0 & 8.0 & 36.5 & 13.5 & 26.4 & 25.7 & 27.1 & 20.3 & 19.6 & 9.8 & 1.3 & 1.8 & 118.5 & 4.8 \\
\hline $\mathrm{Z3}$ & Sep. & 11.7 & 7.0 & 40.5 & 20.1 & 22.4 & 19.4 & 27.5 & 17.6 & 9.2 & 23.4 & 2.4 & 1.6 & 109.5 & 11.3 \\
\hline \multicolumn{16}{|c|}{ Bellamya purificata } \\
\hline $\mathrm{Z} 1$ & Mar. & 3.2 & 2.9 & 5.5 & 85.8 & 70.7 & 137.8 & 16.5 & 14.9 & 4.0 & 15.0 & 355.3 & 90.7 & 2.9 & 1.8 \\
\hline $\mathrm{Z} 1$ & Sep. & 6.6 & 4.5 & 4.2 & 73.5 & 60.0 & 129.4 & 5.8 & 2.7 & 4.2 & 9.6 & 136.0 & 48.7 & 1.1 & 1.1 \\
\hline $\mathrm{Z} 2$ & Mar. & 4.9 & 5.9 & 3.4 & 51.8 & 75.8 & 127.5 & 19.0 & 12.3 & 3.1 & 0.2 & 410.0 & 109.0 & 0.3 & 0.3 \\
\hline $\mathrm{Z} 2$ & Sep. & 8.9 & 7.7 & 4.3 & 262.3 & 62.6 & 127.5 & 3.4 & 2.7 & 7.1 & 0.2 & 120.0 & 37.9 & 4.9 & 21.2 \\
\hline $\mathrm{Z3}$ & Mar. & 6.5 & 4.0 & 5.8 & 258.5 & 64.4 & 152.0 & 0.6 & 3.6 & 4.8 & 0.8 & 366.3 & 102.8 & 2.2 & 3.0 \\
\hline $\mathrm{Z3}$ & Sep. & 4.0 & 3.3 & 5.8 & 229.0 & 57.0 & 108.3 & 7.3 & 4.9 & 6.6 & 4.8 & 130.0 & 41.6 & 10.8 & 4.7 \\
\hline Z9 & Mar. & 6.4 & 4.0 & 7.3 & 66.5 & 58.2 & 53.1 & 3.6 & 1.1 & 2.6 & 5.1 & 7.0 & 2.0 & 11.6 & 9.3 \\
\hline Z9 & Sep. & 6.9 & 4.9 & 2.1 & 57.8 & 32.0 & 61.8 & 3.8 & 1.1 & 7.2 & 3.3 & 93.2 & 57.4 & 7.9 & 11.7 \\
\hline Z10 & Mar. & 5.0 & 4.7 & 4.5 & 107.1 & 75.0 & 75.4 & 15.6 & 4.1 & 2.4 & 15.3 & 12.3 & 4.5 & 1.4 & 9.2 \\
\hline Z10 & Sep. & 6.3 & 7.9 & 4.2 & 62.4 & 77.7 & 88.0 & 3.5 & 2.9 & 7.8 & 0.2 & 70.3 & 79.5 & 20.4 & 1.2 \\
\hline Z11 & Mar. & 5.1 & 5.3 & 4.7 & 90.6 & 88.4 & 98.3 & 14.8 & 7.8 & 2.7 & 19.9 & 47.3 & 25.7 & 1.2 & 1.2 \\
\hline Z11 & Sep. & 14.3 & 16.4 & 14.6 & 105.1 & 74.5 & 83.6 & 14.3 & 17.2 & 14.8 & 33.6 & 28.2 & 17.4 & 10.9 & 10.9 \\
\hline
\end{tabular}


Table S8 Vertical sinking flux of antibiotics out of the water column ( $\left.\mathrm{ng} \mathrm{m}^{-2} \mathrm{~d}^{-1}\right)$.

\begin{tabular}{|c|c|c|c|c|c|c|c|c|c|}
\hline \multirow{2}{*}{ Vertical flux } & \multicolumn{3}{|c|}{ Location 1-2018 } & \multicolumn{3}{|c|}{ Location 2-2018 } & \multicolumn{3}{|c|}{ Location 3-2018 } \\
\hline & Mar & Jul & Sep & Mar & Jul & Sep & Mar & Jul & Sep \\
\hline SDZ & 4.26 & 3.25 & 2.69 & 1.76 & 1.74 & 1.97 & 5.21 & 4.73 & 3.79 \\
\hline SPD & 2.38 & 2.02 & 1.59 & 0.99 & 0.94 & 1.18 & 2.98 & 2.92 & 2.28 \\
\hline $\mathrm{SCT}$ & 2.89 & 8.12 & 6.57 & 0.99 & 1.88 & 1.62 & 15.32 & 13.26 & 13.18 \\
\hline SMZ & 2.65 & 8.20 & 7.23 & 1.48 & 0.83 & 1.64 & 8.37 & 4.89 & 6.54 \\
\hline SMX & 8.25 & 6.10 & 5.41 & 3.35 & 3.35 & 3.79 & 10.04 & 9.58 & 7.29 \\
\hline TMP & 10.33 & 5.20 & 5.25 & 4.60 & 4.85 & 6.53 & 7.87 & 9.33 & 6.32 \\
\hline NFX & 24.27 & 11.25 & 8.12 & 9.72 & 10.73 & 17.27 & 8.41 & 9.84 & 8.95 \\
\hline CFX & 13.41 & 3.80 & 5.53 & 5.89 & 7.28 & 8.47 & 8.49 & 7.39 & 5.72 \\
\hline LFX & 5.53 & 5.97 & 1.77 & 1.80 & 1.37 & 2.22 & 8.89 & 7.14 & 3.00 \\
\hline OFX & 27.81 & 11.69 & 8.97 & 9.90 & 12.65 & 16.77 & 6.72 & 3.57 & 7.60 \\
\hline ETM & 37.61 & 29.09 & 24.98 & 15.49 & 14.53 & 18.00 & 44.39 & 43.03 & 35.60 \\
\hline RTM & 27.23 & 5.33 & 7.78 & 12.64 & 13.99 & 17.12 & 8.06 & 1.75 & 3.68 \\
\hline
\end{tabular}


Table S9 Sediment-to-water diffusion of antibiotics out of the sediment $\left(\mathrm{ng} \mathrm{m}^{-2} \mathrm{~d}^{-1}\right)$.

\begin{tabular}{|c|c|c|c|c|c|c|c|c|c|}
\hline \multirow{2}{*}{ Vertical flux } & \multicolumn{3}{|c|}{ Location 1-2018 } & \multicolumn{3}{|c|}{ Location 2-2018 } & \multicolumn{3}{|c|}{ Location 3-2018 } \\
\hline & Mar & Jul & Sep & Mar & Jul & Sep & Mar & Jul & Sep \\
\hline $\mathrm{SDZ}$ & 1.83 & 2.02 & 3.94 & 3.22 & 4.65 & 5.85 & 0.74 & 1.80 & 4.53 \\
\hline SPD & 0.28 & 1.80 & 0.71 & 0.46 & 0.90 & 0.95 & 0.18 & 0.17 & 0.74 \\
\hline SCT & 11.51 & 26.69 & 25.57 & 19.82 & 32.33 & 36.06 & 7.32 & 8.86 & 24.25 \\
\hline SMZ & 1.84 & 7.71 & 7.51 & 1.94 & 7.78 & 6.27 & 3.29 & 3.17 & 8.68 \\
\hline SMX & 0.18 & 1.00 & 1.87 & 0.41 & 0.61 & 1.96 & 0.44 & 0.61 & 0.65 \\
\hline TMP & 0.99 & 4.37 & 2.23 & 0.87 & 3.43 & 1.88 & 1.28 & 1.47 & 2.18 \\
\hline NFX & 5.65 & 13.05 & 26.78 & 7.99 & 30.37 & 53.51 & 4.42 & 3.46 & 6.36 \\
\hline CFX & 4.03 & 31.30 & 68.23 & 22.80 & 22.84 & 38.14 & 12.95 & 11.62 & 31.32 \\
\hline LFX & 1.45 & 3.00 & 7.00 & 5.45 & 2.02 & 4.32 & 0.66 & 0.52 & 2.94 \\
\hline OFX & 15.98 & 38.11 & 62.64 & 44.49 & 17.88 & 56.20 & 48.01 & 27.26 & 7.94 \\
\hline ETM & 33.79 & 17.35 & 43.40 & 16.86 & 32.55 & 35.95 & 14.18 & 5.64 & 32.68 \\
\hline RTM & 8.16 & 6.23 & 13.03 & 9.80 & 14.10 & 23.13 & 4.50 & 1.28 & 14.17 \\
\hline
\end{tabular}

157 
Table S10 Estimated sediment burial rates of antibiotics $\left(\mathrm{ng} \mathrm{m}^{-2} \mathrm{~d}^{-1}\right)$.

\begin{tabular}{|c|c|c|c|c|c|c|c|c|c|}
\hline \multirow{2}{*}{ Vertical flux } & \multicolumn{3}{|c|}{ Location 1-2018 } & \multicolumn{3}{|c|}{ Location 2-2018 } & \multicolumn{3}{|c|}{ Location 3-2018 } \\
\hline & Mar & Jul & Sep & Mar & Jul & Sep & Mar & Jul & Sep \\
\hline $\mathrm{SDZ}$ & 11.60 & 12.41 & 28.89 & 4.26 & 5.27 & 13.92 & 23.29 & 32.90 & 37.04 \\
\hline SPD & 47.24 & 20.89 & 48.94 & 6.19 & 43.04 & 24.78 & 31.08 & 60.43 & 56.24 \\
\hline SCT & 50.33 & 11.36 & 31.72 & 4.98 & 12.70 & 16.73 & 26.58 & 42.42 & 42.60 \\
\hline SMZ & 180.13 & 160.72 & 126.31 & 11.36 & 51.62 & 69.81 & 36.75 & 144.04 & 104.43 \\
\hline SMX & 101.70 & 34.27 & 97.89 & 4.33 & 22.43 & 56.30 & 27.03 & 36.79 & 105.29 \\
\hline TMP & 96.01 & 67.99 & 87.61 & 11.16 & 53.36 & 39.10 & 30.68 & 116.55 & 60.82 \\
\hline NFX & 90.23 & 87.97 & 79.13 & 6.38 & 16.19 & 45.74 & 28.00 & 104.21 & 164.85 \\
\hline CFX & 149.15 & 144.38 & 94.25 & 1.75 & 14.94 & 44.67 & 30.82 & 30.23 & 45.18 \\
\hline LFX & 45.80 & 25.78 & 35.56 & 4.72 & 10.18 & 32.85 & 52.72 & 19.30 & 36.71 \\
\hline OFX & 66.41 & 37.31 & 101.94 & 8.86 & 22.90 & 51.38 & 75.52 & 29.88 & 83.42 \\
\hline ETM & 56.79 & 77.30 & 106.88 & 37.43 & 21.33 & 72.54 & 58.04 & 110.17 & 109.21 \\
\hline RTM & 117.08 & 189.50 & 173.77 & 36.57 & 31.42 & 89.57 & 136.98 & 191.71 & 285.41 \\
\hline
\end{tabular}

160 
Table S11 Biodegradability of the target biodegradable antibiotics.

\begin{tabular}{|c|c|c|c|c|c|c|}
\hline \multirow{2}{*}{ Name } & \multicolumn{4}{|c|}{ Biodegradability } & \multicolumn{2}{|c|}{ Classification } \\
\hline & Linear & Non-Linear & MITI Linear & MITI Non-Linear & Ultimate Biodegradation & Primary Biodegradation \\
\hline SDZ & 0.3946 & 0.0793 & -0.1326 & 0.0062 & 2.5111 & 3.3783 \\
\hline SPD & 0.2405 & 0.0167 & -0.1549 & 0.0045 & 2.2992 & 3.361 \\
\hline SCT & 0.4118 & 0.1256 & -0.0496 & 0.0123 & 2.5908 & 3.4303 \\
\hline SMZ & 0.4906 & 0.1549 & -0.1496 & 0.004 & 2.2994 & 3.2007 \\
\hline SMX & 0.4497 & 0.1281 & -0.1165 & 0.006 & 2.4297 & 3.3054 \\
\hline TMP & 0.5922 & 0.9164 & 0.0889 & 0.0172 & 2.0385 & 3.3749 \\
\hline NFX & -0.3916 & 0 & 0.0934 & 0.0001 & 1.9435 & 3.2311 \\
\hline CFX & -0.3974 & 0 & 0.0597 & 0.0001 & 1.917 & 3.2138 \\
\hline LFX & -1.2169 & 0 & 0.0004 & 0 & 1.4658 & 3.1984 \\
\hline OFX & -0.3081 & 0 & -0.1754 & 0 & 1.9696 & 2.816 \\
\hline OTC & 0.771 & 0.041 & 0.3781 & 0.0077 & 1.9397 & 3.1776 \\
\hline $\mathrm{TC}$ & 0.6199 & 0.0173 & 0.2719 & 0.0065 & 1.8151 & 3.0712 \\
\hline ETM & -1.4385 & 0 & -0.1005 & 0 & 1.2404 & 2.5869 \\
\hline RTM & -2.1892 & 0 & -0.3734 & 0 & 1.0176 & 2.4409 \\
\hline
\end{tabular}

163 For Ultimate Biodegradation Timeframe and Primary Biodegradation Timeframe models, based on expert knowledge acquired in a survey, classification of rates was 164 described according to the numerical value, with 5.00, 4.00, 3.00, 2.00 and 1.00 indicate degradation in hours, days, weeks, months and longer than months, respectively, 165 and a threshold of 2.5 for the ultimate biodegradation model and of 3.5 for the primary biodegradation model. 
Table S12 Physical parameters of water in different sampling sites in Pearl River in 2018.

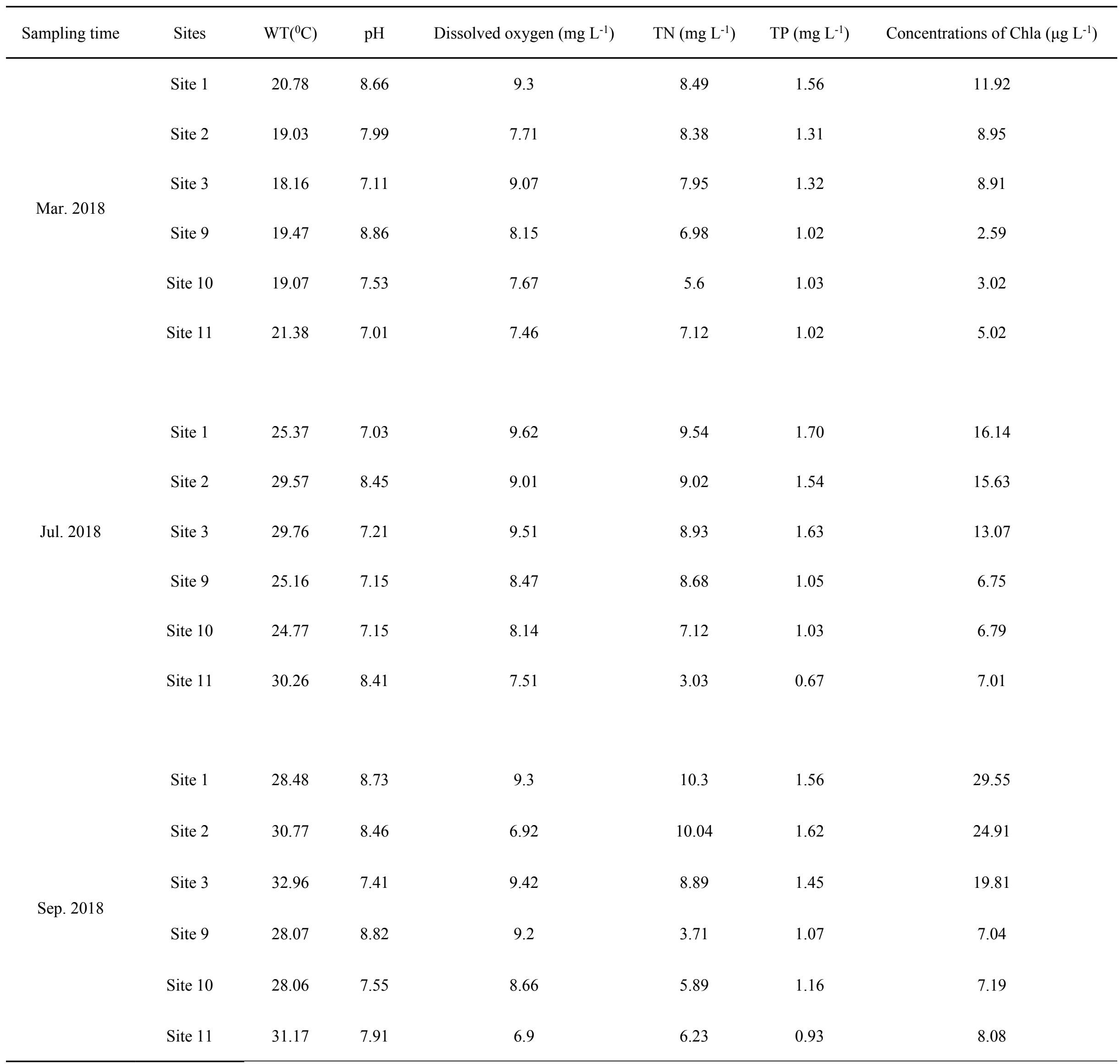




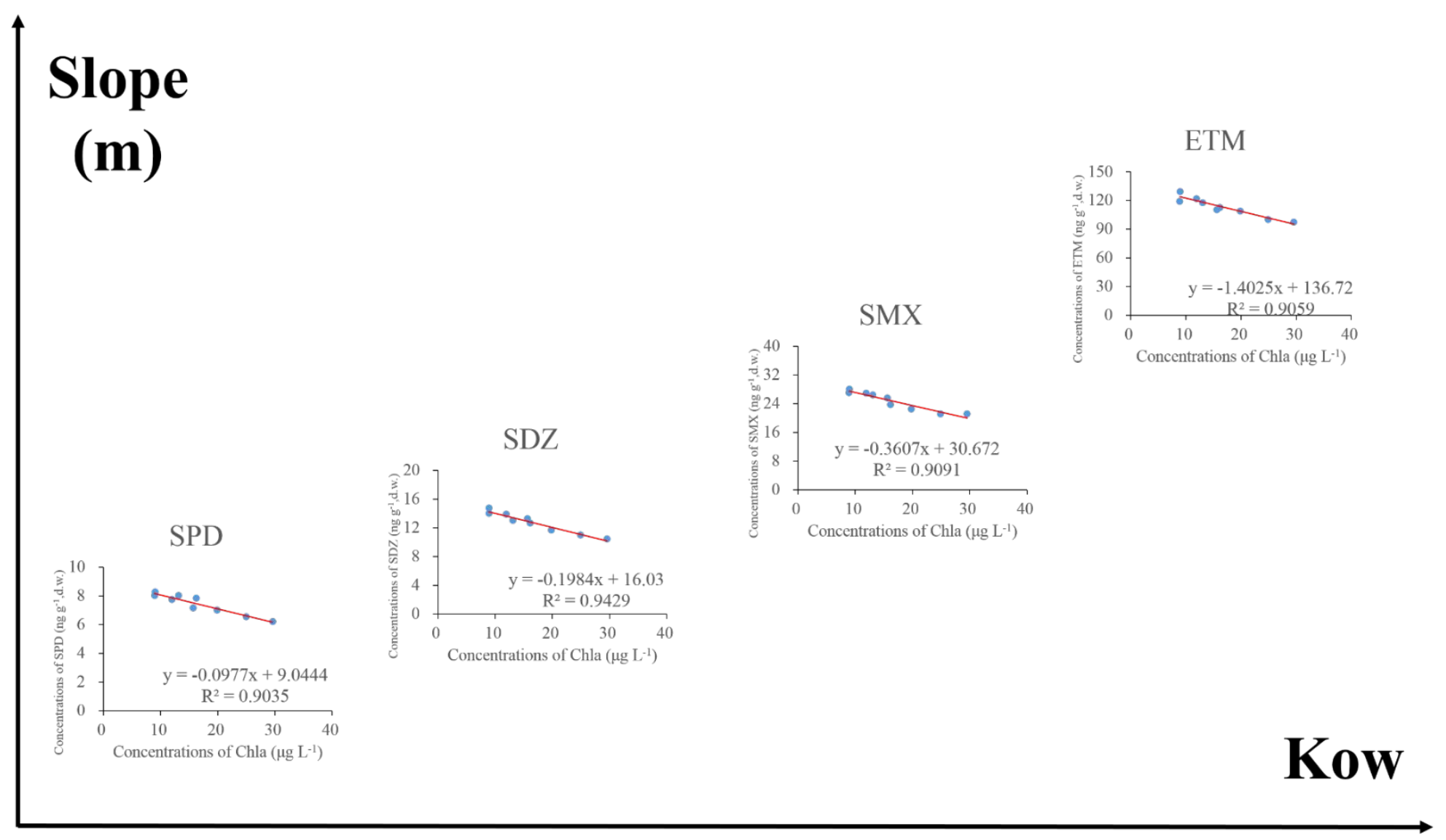


OTC

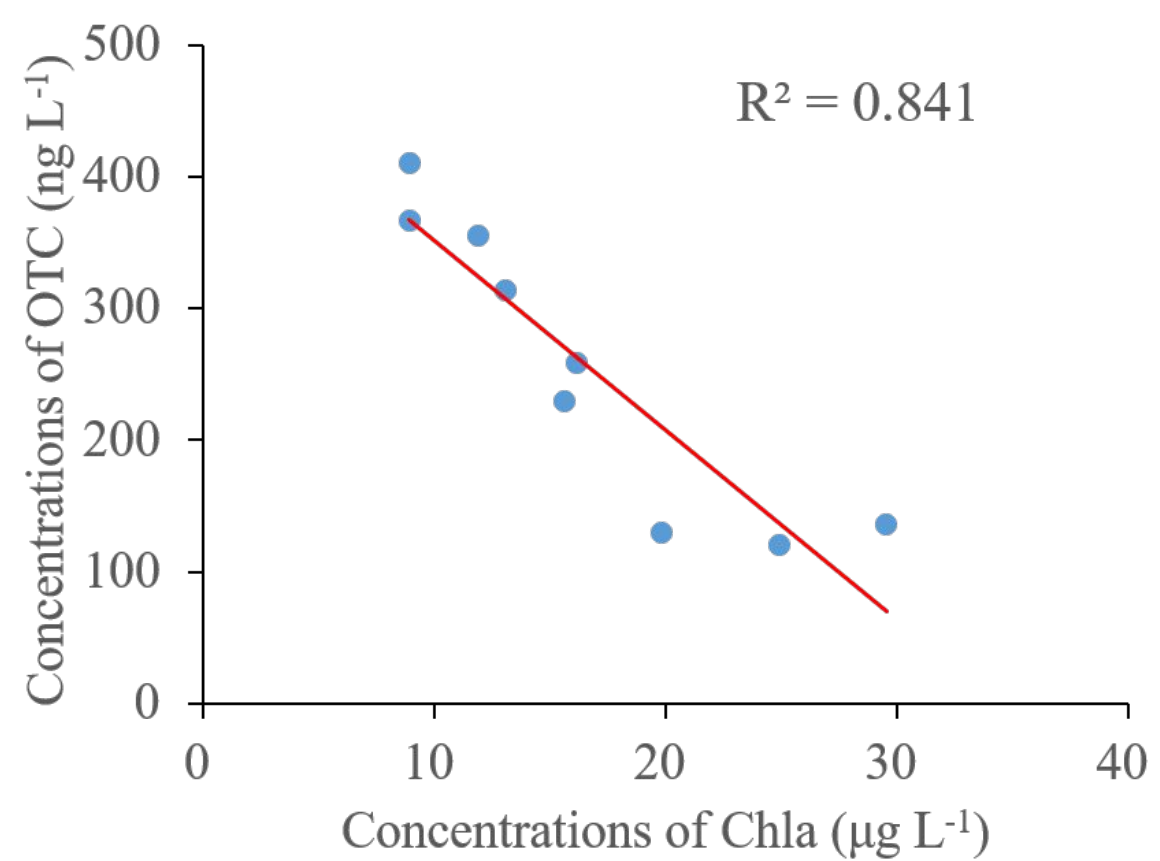

TC

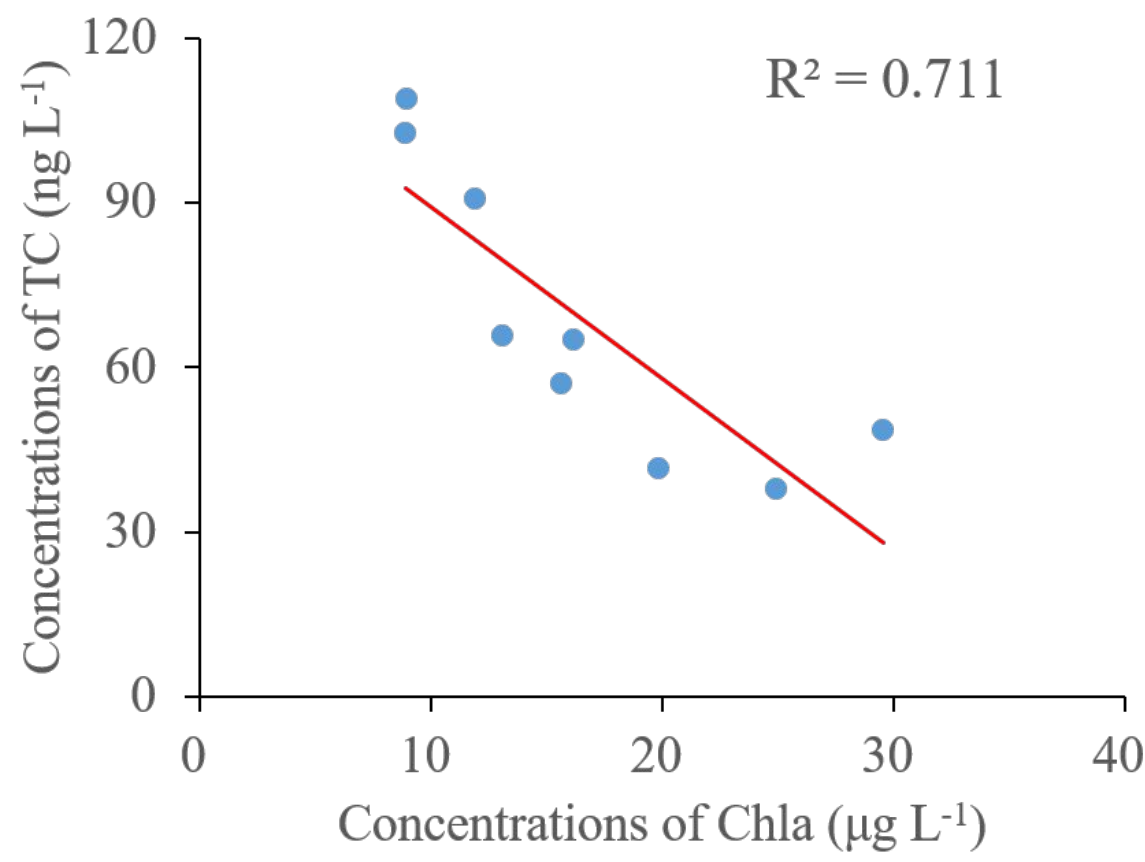

174

175

176

Figure S2 Regression of concentrations of OTC and TC, the biodegradable contaminants in the water with Chla in the water column at locations 1 to 3 during March, July and September in 2018 . 


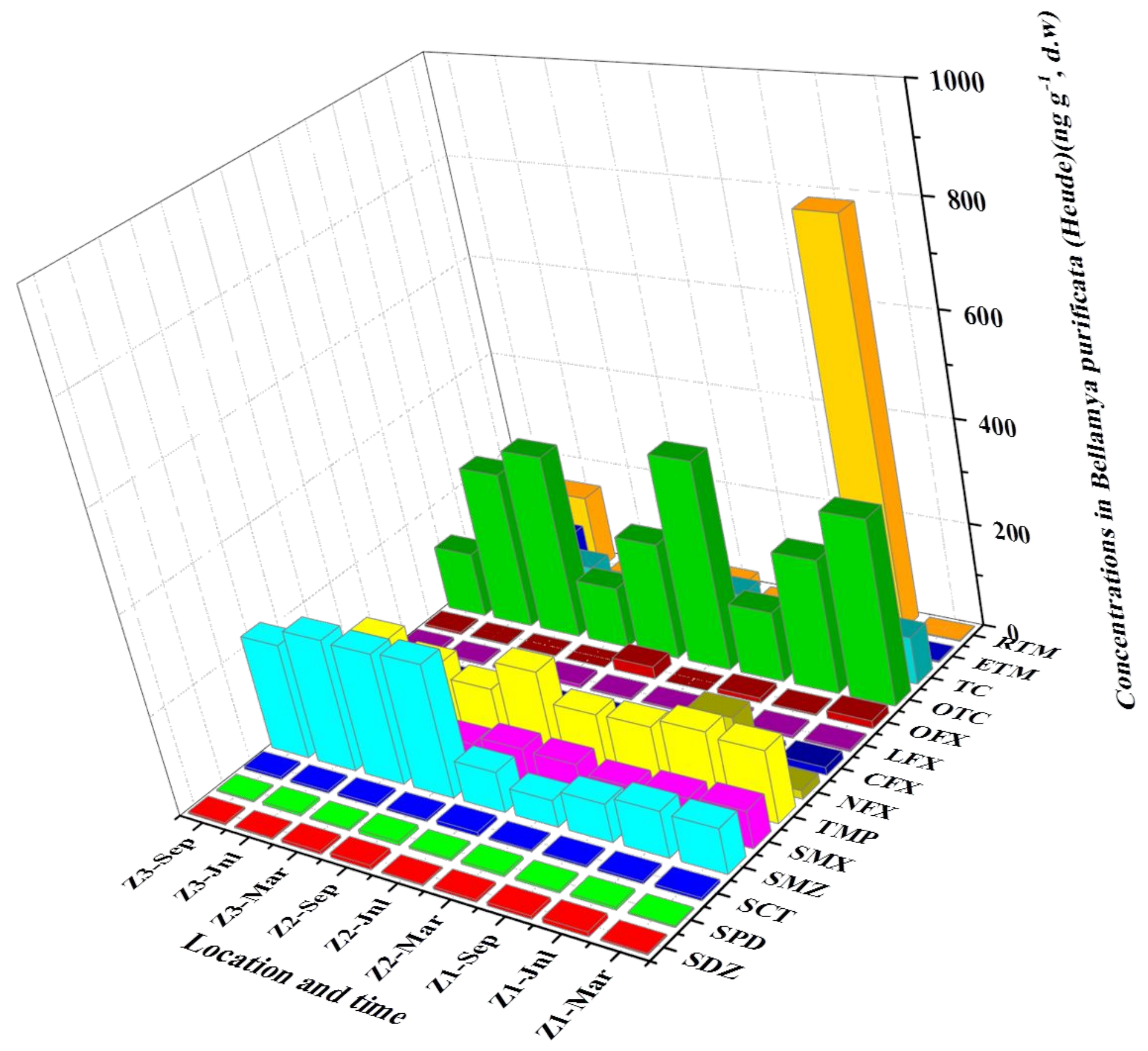




\section{References:}

(1) Lu, F.-H.; Ni, H.-G.; Liu, F.; Zeng, E. Y., Occurrence of nutrients in riverine runoff of the Pearl River Delta, South China. JHyd 2009, 376, (1-2), 107-115.

(2) Mai, B. X.; Fu, J. M.; Zhang, G.; Lin, Z.; Min, Y. S.; Sheng, G. Y.; Wang, X. M., Polycyclic aromatic hydrocarbons in sediments from the Pearl river and estuary,

China: spatial and temporal distribution and sources. Appl. Geochem. 2001, 16, (11-12), 1429-1445.

(3) Xie, H.; Hao, H.; Xu, N.; Liang, X.; Gao, D.; Xu, Y.; Gao, Y.; Tao, H.; Wong, M., Pharmaceuticals and personal care products in water, sediments, aquatic organisms, and fish feeds in the Pearl River Delta: Occurrence, distribution, potential sources, and health risk assessment. Sci. Total. Environ. 2019, 659, $230-239$.

(4) Li, S.; Shi, W.; Liu, W.; Li, H.; Zhang, W.; Hu, J.; Ke, Y.; Sun, W.; Ni, J., A duodecennial national synthesis of antibiotics in China's major rivers and seas (20052016). Sci. Total. Environ. 2018, 615, 906-917.

(5) Zhang, Q. Q.; Ying, G. G.; Pan, C. G.; Liu, Y. S.; Zhao, J. L., Comprehensive evaluation of antibiotics emission and fate in the river basins of China: Source analysis, multimedia modeling, and linkage to bacterial resistance. Environ. Sci. Technol. 2015, 49, (11), 6772-6782.

(6) Yang, J. F.; Ying, G. G.; Zhao, J. L.; Tao, R.; Su, H. C.; Liu, Y. S., Spatial and seasonal distribution of selected antibiotics in surface waters of the Pearl Rivers, China. J Environ Sci Heal B 2011, 46, (3), 272-280.

(7) Ma, J.; Brookes, J. D.; Qin, B.; Paerl, H. W.; Gao, G.; Wu, P.; Zhang, W.; Deng, J.; Zhu, G.; Zhang, Y.; Xu, H.; Niu, H., Environmental factors controlling colony formation in blooms of the cyanobacteria Microcystis spp. in Lake Taihu, China. Harmful Algae 2014, 31, 136-142.

(8) Long, S.; Hamilton, P. B.; Dumont, H. J.; Rong, L.; Wu, Z.; Chen, C.; Guo, Y.; Tang, J.; Fan, J.; Li, C.; Zhang, T., Effect of algal and bacterial diet on metal bioaccumulation in zooplankton from the Pearl River, South China. Sci. Total. Environ. 2019, 675, 151-164.

(9) Tao, Y.; Yu, J.; Xue, B.; Yao, S.; Wang, S., Precipitation and temperature drive seasonal variation in bioaccumulation of polycyclic aromatic hydrocarbons in the planktonic food webs of a subtropical shallow eutrophic lake in China. Sci. Total. Environ. 2017, 583, 447-457.

(10) Tao, Y.; Yu, J.; Lei, G.; Xue, B.; Zhang, F.; Yao, S., Indirect influence of eutrophication on air - water exchange fluxes, sinking fluxes, and occurrence of polycyclic aromatic hydrocarbons. Water. Res. 2017, 122, 512-525.

(11) Hu, H.-J.; Li, R.; Wei, Y.; Zhu, H.; Chen, J.; Shi, Z., Freshwater algae in China. Shanghai Science and Technology Press, Shanghai (in Chinese): 1980.

(12) Pápista, É.; Ács, É.; Böddi, B., Chlorophyll-a determination with ethanol - A critical test. Hydrobiologia 2002, 485, $191-198$.

(13) Guo, C. N.; Wang, M. R.; Xiao, H.; Huai, B. B.; Wang, F.; Pan, G. F.; Liao, X. P.; Liu, Y. H., Development of a modified QuEChERS method for the determination of veterinary antibiotics in swine manure by liquid chromatography tandem mass spectrometry. J. Chromatogr. B 2016, 1027, 110-118.

(14) Tai, Y. P.; Tam, N. F. Y.; Ruan, W. F.; Yang, Y. F.; Yang, Y.; Tao, R.; Zhang, J. F., Specific metabolism related to sulfonamide tolerance and uptake in wetland plants. Chemosphere. 2019, 227, 496-504. 
(15) Li, Y.; Sallach, J. B.; Zhang, W.; Boyd, S. A.; Li, H., Insight into the distribution of pharmaceuticals in soil-water-plant systems. Water. Res. 2019, 152, 38-46.

(16) Kelly, B. C.; Ikonomou, M. G.; Blair, J. D.; Morin, A. E.; Gobas, F. A. P. C., Food web-specific biomagnification of persistent organic pollutants. Science 2007, 317, (5835), 236-239.

(17) Berrojalbiz, N.; Dachs, J.; Del Vento, S.; Ojeda, M. J.; Valle, M. C.; Castro-Jiménez, J.; Mariani, G.; Wollgast, J.; Hanke, G., Persistent organic pollutants in mediterranean seawater and processes affecting their accumulation in plankton. Environ. Sci. Technol. 2011, 45, (10), 4315-4322.

(18) Nizzetto, L.; Gioia, R.; Li, J.; Borga, K.; Pomati, F.; Bettinetti, R.; Dachs, J.; Jones, K. C., Biological pump control of the fate and distribution of hydrophobic organic pollutants in water and plankton. Environ. Sci. Technol. 2012, 46, (6), 3204-3211.

(19) Stange, K.; Swackhamer, D. L., Factors affecting phytoplankton species - specific differences in accumulation of 40 polychlorinated biphenyls (PCBs). Environ. Toxicol. Chem. 1994, 13, (11), 1849-1860.

(20) Tang, J.; Wang, S.; Tai, Y.; Tam, N. F.; Su, L.; Shi, Y.; Luo, B.; Tao, R.; Yang, Y.; Zhang, X., Evaluation of factors influencing annual occurrence, bioaccumulation, and biomagnification of antibiotics in planktonic food webs of a large subtropical river in South China. Water. Res. 2019, 170, 115302-115302.

(21) Meijer, S. N.; Dachs, J.; Fernandez, P.; Camarero, L.; Catalan, J.; Del Vento, S.; Van Drooge, B.; Jurado, E.; Grimalt, J. O., Modelling the dynamic air-water-sediment coupled fluxes and occurrence of polychlorinated biphenyls in a high altitude lake. Environ. Pollut. 2006, 140, (3), 546-560.

(22) Qiao, M.; Huang, S.; Wang, Z., Partitioning characteristics of PAHs between sediment and water in a shallow lake. J. Soils Sed. 2008, 8, (2), 69-73.

(23) Zhu, G.; Qin, B.; Gao, G.; Zhang, L.; Luo, L.; Zhang, Y., Effects of hydrodynamics on phosphorus concentrations in water of Lake Taihu, a large, shallow, eutrophic lake of China. Hydrobiologia 2007, 581, 53-61.

(24) Fan, C. X.; Zhang, L.; Qu, T. C., Lake sediment resuspension and caused phosphate release - a simulation study. JEnvS 2001, 13, (4), 406-410.

(25) Imboden, D.; Schwarzenbach, R. J. C. P. i. L., John Wiley; Sons, N. Y. N. Y. p.-., 8 fig, 7 tab, 23 ref., Spatial and temporal distribution of chemical substances in lakes: modeling concepts. 1985. 